\title{
Acute organo-phosphorus pesticide poisoning, oxidative damage, haemoglobin level and total leukocyte
}

Sir, the recent report on acute organo-phosphorus pesticide poisoning, oxidative damage, haemoglobin level and total leukocyte is very interesting [1]. Hundekari et al. noted that "cholinesterase inhibition may initiate cellular dysfunction leading to acetylcholine induced oxidative damage [1]." This work is very useful information in clinical toxicology. However, there are many points to be considered. First, there is no control group in this report and it is not possible to tell whether the observed finding is significantly different from general population in the same area. In many rural areas in developing countries, the exposure to organo-phosphorus pesticide is common and the abnormal cholinesterase activity can be seen [2]. Focusing on the present study, the question is on whether there is any underlying disease affecting haemoglobin among the subjects. It should be reminded that the hemoglobinopathy can affect haemoglobin level and show the figure of abnormal oxidative status [3].

Viroj Wiwanitkit

Joseph Ayobabalola Hainan Medical University, China, Faculty of Medicine, University of Nis, Serbia; adjunct University, Nigeria;

Chulalongkorn University, Bangkok Thailand

DOI: http://dx.doi.org/10.4314/ahs.v14i3.42

\section{References}

1. Hundekari IA, Suryakar AN, Rathi DB. Acute organo-phosphorus pesticide poisoning in North Karnataka, India: oxidative damage, haemoglobin level and total leukocyte. Afr Health Sci. 2013 Mar;13(1):129-36.

2. Soogarun S, Wiwanitkit V, Suyaphan A, Suwansaksri J, Pathompattama N. Decreased serum cholinesterase levels among a sample of a rural Thai population. MedGenMed. 2003 Jun 12;5(2):30

3. Palasuwan A, Kittisakulrat T, Amornrit W, Soogarun S, Wiwanitkit V, Pradniwat P. Antioxidant in plasma of hemoglobin-E trait. Southeast Asian J Trop Med Public Health. 2005;36 Suppl 4:271-3. 